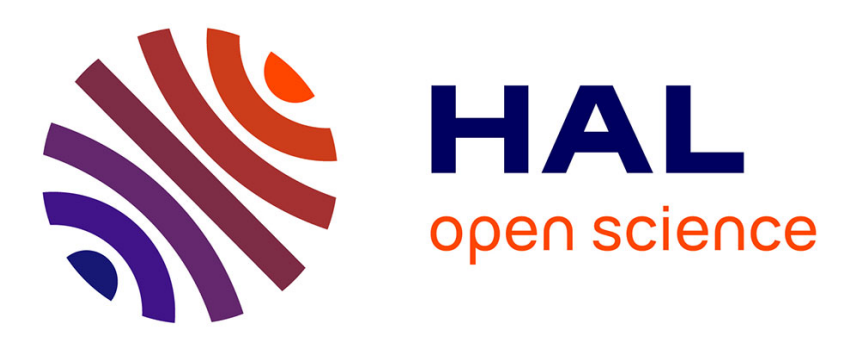

\title{
Neutron study of Al or Mn substituted LaNi5 hydrogen sponges
}

\author{
J. Achard, F. Givord, A. Percheron-Guegan, J. Soubeyroux, F. Tasset
}

\section{To cite this version:}

J. Achard, F. Givord, A. Percheron-Guegan, J. Soubeyroux, F. Tasset. Neutron study of Al or Mn substituted LaNi5 hydrogen sponges. Journal de Physique Colloques, 1979, 40 (C5), pp.C5-218-C5220. 10.1051/jphyscol:1979582 . jpa-00218999

\section{HAL Id: jpa-00218999 https://hal.science/jpa-00218999}

Submitted on 1 Jan 1979

HAL is a multi-disciplinary open access archive for the deposit and dissemination of scientific research documents, whether they are published or not. The documents may come from teaching and research institutions in France or abroad, or from public or private research centers.
L'archive ouverte pluridisciplinaire HAL, est destinée au dépôt et à la diffusion de documents scientifiques de niveau recherche, publiés ou non, émanant des établissements d'enseignement et de recherche français ou étrangers, des laboratoires publics ou privés. 


\title{
Neutron study of $\mathrm{Al}$ or $\mathrm{Mn}$ substituted $\mathrm{LaNi}_{5}$ hydrogen sponges
}

\author{
J. C. Achard $\left({ }^{*}\right)$, F. Givord $\left({ }^{* *}\right)$, A. Percheron-Guegan $\left({ }^{*}\right)$, J. L. Soubeyroux $\left({ }^{* * *}\right)$ and F. Tasset $\left({ }^{* * *}\right)$ \\ $\left(^{*}\right)$ ER 209 C.M.S. Terres Rares, 92190 Bellevue Meudon, France \\ (**) Laboratoire Louis-Néel, 166X, 38042 Grenoble Cedex, France \\ (***) ILL, 156X, 38042 Grenoble Cedex, France
}

\begin{abstract}
Résumé. - La diffraction des neutrons montre que les substitutions de Al et $\mathrm{Mn}$ occupent principalement le site $3 \mathrm{~g}_{\text {dans }} \mathrm{LaNi}_{5}$. La largeur anormale des raies de diffraction du composé $\mathrm{LaNi}_{5}$ activé montre que les grains sont subdivisés en filaments. Cette anomalie disparaît pour les composés substitués.
\end{abstract}

\begin{abstract}
Neutron diffraction measurements show that substituted $\mathrm{Al}$ and $\mathrm{Mn}$ atoms occupy mainly the $3 \mathrm{~g}$ site in $\mathrm{LaNi}_{5}$. The anomalous width of activated $\mathrm{LaNi}_{5}$ diffraction lines shows that the grains are subdivided into filaments. These anomalies disappear for substituted compounds.
\end{abstract}

1. Introduction. - Partial substitution of $\mathrm{La}$ or $\mathrm{Ni}$ changes the equilibrium pressure of the related reversible hydride [1] proportionally to the primary intermetallic cell volume change [2,3]. Little evidence has been obtained to date about the action of such substitution on the hydrogen content. Following already published neutron diffraction $[4,5]$ and NMR $[6,7]$ results for the non substituted $\mathrm{LaNi}_{5} \mathrm{H}_{6}$, the aim of our work is to determine the position of the substitutions and the hydrogen sites in substituted compounds.

2. Sample characterization. - Intermetallic compounds were prepared as described in ref. [8]. Upper limits for substitutions correspond to $\mathrm{LaN1}_{3.8} \mathrm{Al}_{1.2}$ and $\mathrm{LaNi}_{2.7} \mathrm{Mn}_{2.25}$. Homogeneous activated powder (5-15 $\mu$ particle size) was obtained after several absorption-desorption hydrogen cycles $(40$ bar at

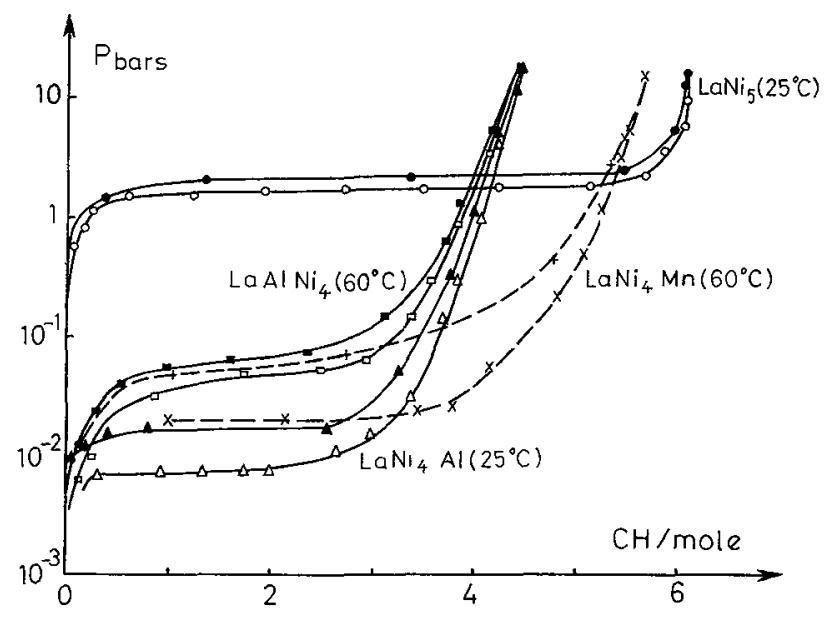

Fig. 1. - Comparison of absorption-desorption isotherms for $\mathrm{LaNi}_{5}, \mathrm{LaNi}_{4} \mathrm{Al}$ at $25^{\circ} \mathrm{C}$ and $\mathrm{LaNi}_{4} \mathrm{Mn}, \mathrm{LaNi}_{4} \mathrm{Al}$ at $60^{\circ} \mathrm{C}$. $\left.40^{\circ} \mathrm{C}\right)$. Shown on figure 1 are typical composition isotherms determined as explained in ref. [9]. The replacement of hydrogen by deuterium does not change the capacity of the $\beta$ phase.

3. Crystal structure and grain size of intermetallic compounds. - 3.1 EXPERIMENTAL. - D1A and D1B multidetector powder diffractometer of the Institut Laüe Langevin were used for neutron measurements. Scattering by the $1 \mathrm{~mm}$ thick quartz container was easy to correct for. The deuterium pressure ( $0-10$ bar $)$ applied to the sample was continuously monitored.

3.2 $\mathrm{LaNi}_{5}$ ALLOY. - An obvious broadening of $h k 0$ lines relative to the instrument resolution of the D1A diffractometer was detected. This indicates a lack of long range coherence in the $(a, b)$ crystalline plane. On the contrary the narrower width of $00 l$ diffraction lines shows that there is coherence along the $C$ axis leading to a very anısotropic, filament like, metallic sponge model for these activated grains. Complementary high resolution X-ray measurements are being made on this interesting phenomenon. Intensities of individual reflections were determined by fitting gaussian peak shapes and from these the structure was refined. The $\mathrm{P} 6 t_{\mathrm{m}} \mathrm{mm}$ space group with $\mathrm{La}$ atoms on 1a site and $\mathrm{Ni}$ atoms on $2 \mathrm{c}$ and $3 \mathrm{~g}$ sites leads to an $R$-factor of $2.9 \%$, the stoichiometric effect being reflected in the replacement of $2 \% \mathrm{La}$ by pairs of $\mathrm{Ni}$ in $2 \mathrm{e}$ positions [table I], [10].

$3.3 \mathrm{LaNi}_{5-x} \mathrm{M}_{x}$ ALLOYS $(\mathrm{M}=\mathrm{Al}, \mathrm{Mn} ; 0.5<x<2)$. - The breadth of diffraction lines found is normal so that the standard profile refinement technique [11] can be used. The same $P 6 / \mathrm{mm}$ space group leads to the results of table $\mathrm{I}$. The $\mathbf{M}$ atoms exhibit a strong 
Table I. - Intermetallic compounds $\mathrm{LaNi}_{5-x} \mathbf{M}_{x}$

\begin{tabular}{|c|c|c|c|c|c|c|}
\hline Comp. & $\mathrm{La}_{1-\mathrm{s}} \mathrm{Ni}_{5+2 \mathrm{~s}}$ & $\mathrm{LaNi}_{4.5} \mathrm{Al}_{0.5}$ & $\begin{array}{c}\mathrm{LaNi}_{4} \mathrm{Al} \\
-\end{array}$ & $\mathrm{LaNi}_{4.5} \mathrm{Mn}_{0.5}$ & $\underset{-}{\mathrm{LaNi}_{4} \mathrm{Mn}}$ & $\begin{array}{c}\mathrm{LaNi}_{3} \mathrm{Mn}_{2} \\
-\end{array}$ \\
\hline$a(\AA)$ & $5.017(1)$ & $5.031(1)$ & $5.063(1)$ & $5.042(1)$ & $5.096(1)$ & $5.162(1)$ \\
\hline$c(\AA)$ & $3.993(2)$ & $4.019(1)$ & $4.063(1)$ & $4.014(1)$ & $4.075(1)$ & $4.135(1)$ \\
\hline $\mathrm{s}_{\mathrm{La}}$ & $0.020(3)$ & $0.036(7)$ & $0.024(8)$ & $0.027(7)$ & $0.021(6)$ & $0.016(6)$ \\
\hline$f_{1}(z=0)$ & & $0.08(6)$ & $0.12(8)$ & $0.06(2)$ & $0.23(5)$ & $0.28(3)$ \\
\hline$j_{2}\left(z=\frac{1}{2}\right)$ & & $0.42(9)$ & $0.94(10)$ & $0.40(3)$ & $0.90(5)$ & $1.62(2)$ \\
\hline $\mathrm{B}_{\mathrm{La}}$ & $1.0(2)$ & $0.75(20)$ & $0.87(25)$ & $0.70(14)$ & $1.35(25)$ & $0.6(2)$ \\
\hline $\mathrm{B}_{\mathrm{Ni}}$ & $0.8(1)$ & $0.6(1)$ & $0.5(1)$ & $0.6(1)$ & $0.66(7)$ & $0.90(15)$ \\
\hline $\mathrm{B}_{\mathrm{M}}$ & & $0.6(1)$ & $0.5(1)$ & $0.6(1)$ & $0.66(7)$ & $0.90(15)$ \\
\hline Final & $\mathrm{La} \quad \mathrm{Ni}$ & La Ni Al & $\mathrm{La} \quad \mathrm{Ni} \quad \mathrm{Al}$ & $\mathrm{La} \quad \mathrm{Ni} \mathrm{Mn}$ & $\mathrm{La} \quad \mathrm{Ni} \mathrm{Mn}$ & La Ni N \\
\hline Comp. & 0.985 .04 & $\begin{array}{lll}0.96 & 4.58 & 0.5\end{array}$ & $\begin{array}{lll}0.98 & 3.98 & 1.06\end{array}$ & $\begin{array}{lll}0.97 & 4.6 & 0.46\end{array}$ & $\begin{array}{lll}0.98 & 3.9 & 1.13\end{array}$ & $0.98 \quad 3.141$ \\
\hline Residu & $2.9 \%$ & $5.6 \%$ & $8.6 \%$ & $6.0 \%$ & $8.4 \%$ & $8.9 \%$ \\
\hline
\end{tabular}

Table II. - Hydrides of intermetallic compounds

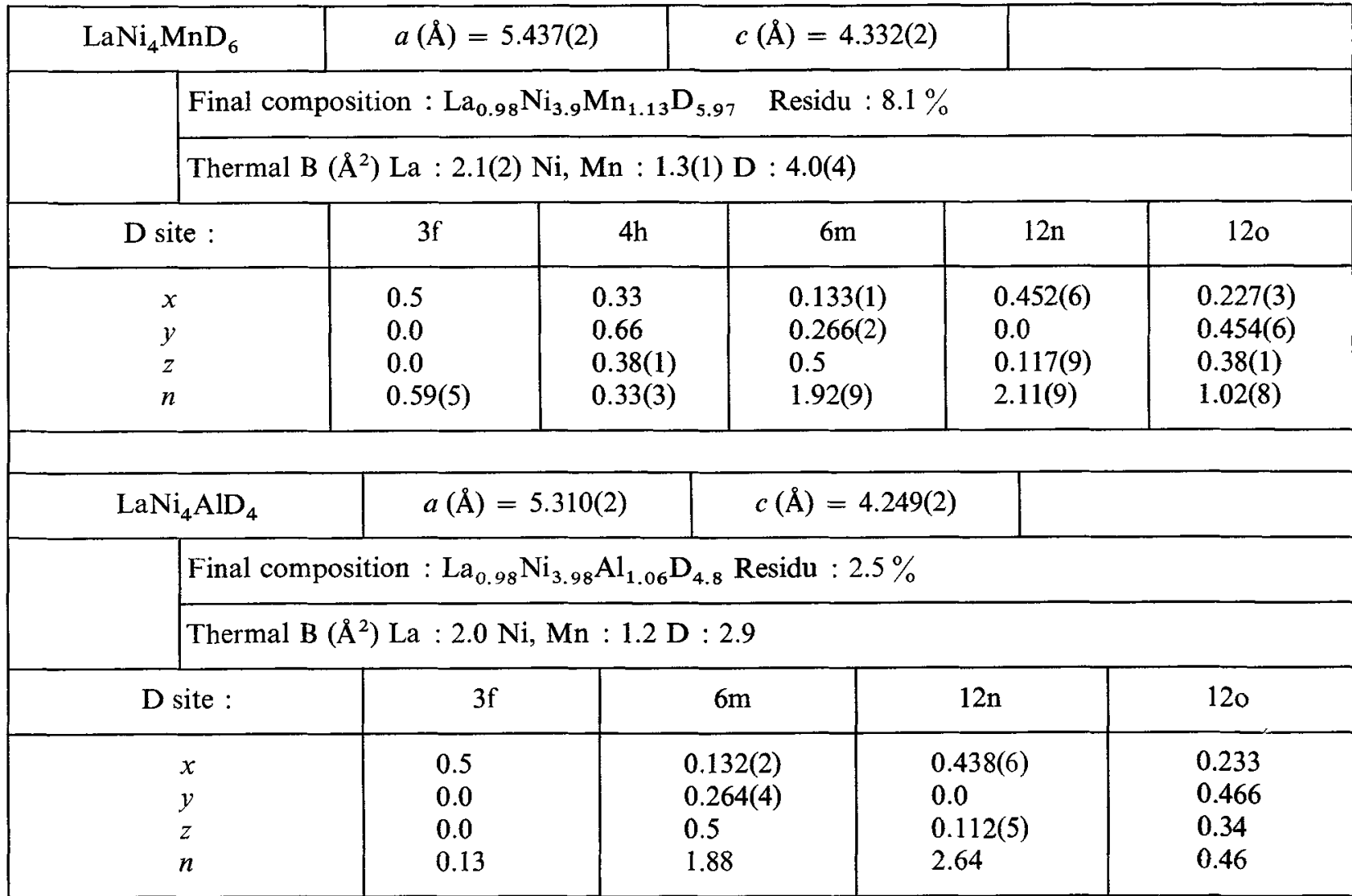

preference for the $3 \mathrm{~g}$ site (amount $\mathrm{S}_{2}$ ) relative to the $2 \mathrm{c}$ site (amount $\mathrm{S}_{1}$ ). There is no obvious difference in the behaviour of $\mathrm{Al}$ and $\mathrm{Mn}$ atoms.

4. Crystal structure of substituted $\mathrm{LaNi}_{5-x} \mathbf{M}_{x} \mathbf{D}_{y}$ hydrides. - Deuterides were used to reduce neutron incoherent scattering. Using the Rietveld technique we have found possible structures for $\mathrm{LaN}_{4} \mathrm{MnD}_{6}$

Fig. 2. - Neutron diffractogram of $\mathrm{LaNi}_{5}(\mathrm{D} 1 \mathrm{~A}: \lambda=1.909 \AA)$.

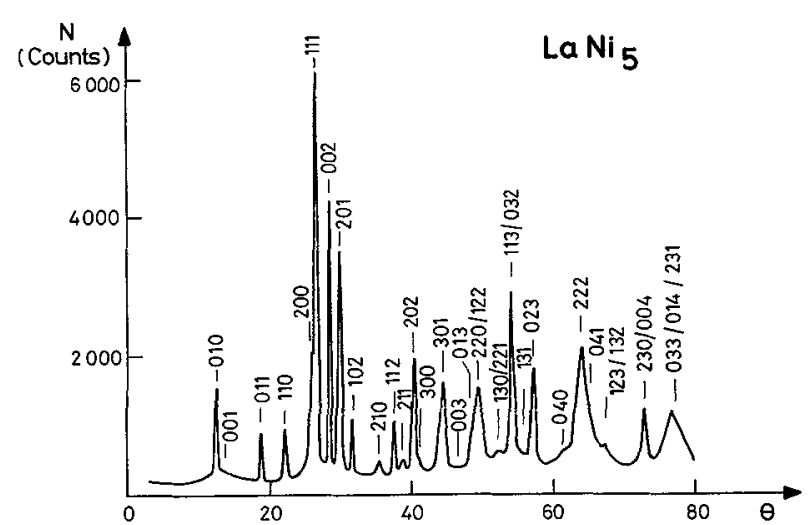


and $\mathrm{LaNi}_{4} \mathrm{AlD}_{4}$ [table II]. Although deuterıum atoms are widely distributed on possible sites in qualitative agreement with NMR results $[8,9]$, some preference exists for the $6 \mathrm{~m}$ site.

5. Conclusion. - We have determined the crystal structure of $\mathrm{LaNi}_{5}$ and substituted $\mathrm{Al}$ and $\mathrm{Mn}$ alloys. An interesting difference appears to be the existence of subgrains in activated $\mathrm{LaNi}_{5}$ which could be of some importance in rapid hydrogen uptake. We found no obvious correlation between changes of crystal structure and hydrogen content. Complementary X-ray and neutron diffraction measurements are now being made and should help for a better understanding of this interesting class of substituted compounds.

\section{Reference}

[1] Zijlstra, H. and Westendrop, F., Solid State Commun. 7 (1969) 857.

[2] Van Vucht, J. H. N., KuiJPers, F. A., Bruning, H. C., Philips Res. Reports 25 (1970) 133.

[3] Van Mal, H. H., Buschow, K. H. J., Miedema, A. R., J. Less-Common Met. 35 (1974) 65.

[4] Bowman, A. L., Anderson, J. L., Nereson, N. G., Proceedings Tenth Rare Earth Res. Conf. Carefree Arizona (1973) 485.

[5] Fischer, P., Furrer, A., Busch, G., Schlapbach, L., Helv. Phys. Acta 50 (1977) 421.

[6] Halstead, T. K., J. Solid State Chem. 11 (1974) 114.
[7] Barnes, R. G., Harper, W. C., Nelson, S. O., Meeting Hydrogen in Metals, Birmingham 1976.

[8] Percheron-Guegan, A., Schlapbach, L., Achard, J. C., Sarradin, J., BronoËL, G., Société Chimique de France, septembre 1974.

[9] Achard, J. C., Percheron-Guegan, A., Diaz, H., Proceedings of 2nd International Congress Hydrogen in Metals, Paris France 8 (1977) 1 E12.

[10] TASSET, F., Thesis no. A.O. 10916 Grenoble (1975).

[11] Rietveld, H. M., Acta Cryst. 22 (1967) 151. 